\title{
THE ROLE OF TRUST IN RELATIONSHIP DEVELOPMENT AND PERFORMANCE IMPROVEMENT
}

\author{
Xianhai MENG \\ School of Planning, Architecture and Civil Engineering, Queen's University Belfast, David Keir Building, \\ Stranmillis Road, BT9 5 AG Belfast, UK
}

Received 04 Apr 2012; accepted 11 Feb 2013

\begin{abstract}
The importance of inter-organizational trust to project success has been increasingly highlighted in the construction industry. This study aims to explore the role of trust between project parties. It adopts a combination of quantitative and qualitative methodologies. Based on the analysis of the responses of a questionnaire survey, trust is demonstrated to have a significant contribution to the development of cooperative or collaborative relationships; fostering trust proves to have a major influence on the improvement of project performance; and some relationship and performance indicators are found to have closer associations with trust than others so that trust is more important to the development of relationship and the improvement of performance in these aspects. The analysis of questionnaire responses also provides significant evidence for the reduction in monitoring and control following the increase of mutual trust. The questionnaire survey is followed by a series of expert interviews, both of which contribute to the establishment of a model that links trust with relationship and performance and distinguishes the new approach that is based on trust from the traditional mechanism that relies on monitoring and control.
\end{abstract}

Keywords: trust, relationship, performance, construction.

\section{Introduction}

Traditionally, construction project management is based on contracts and relies on monitoring and control techniques (Al-Jibouri 2003; Zaghloul, Hartman 2003). The traditional management theory has a fixed view of management and can be described as a 'hard' management system (Walker 2007). It often suffers from various problems. According to Turner (2004) and Rahman and Kumaraswamy (2004), a major problem of the traditional system is a lack of flexibility to deal with unforeseen circumstances. Therefore, it is usually nearsighted and reactive. Although the contract in a project is regarded as a standard of behavior, due to transaction costs, bounded rationality and information asymmetries, every project contract is almost certainly incomplete (Turner 2004; Badenfelt 2011). The unavoidable nature of contract incompleteness becomes another traditional problem that easily results in uncertainty and dispute. On the other hand, heavy reliance on monitoring and control in a traditional system often causes adversarial or confrontational relationships and entails hidden costs (Cheung et al. 2003; Lann et al. 2011). For all these reasons, traditional practices form barriers to project success and proliferate opportunities for poor performance, such as time delays, cost overruns and quality defects.
In recent years, relationship management has received an increasing attention from construction researchers and practitioners. For example, Smyth and Fitch (2009) presented the application of relationship marketing and management for large construction contractors. Compared to 'hard' monitoring and control, the relationship methodology represents a 'soft' management system (Walker 2007). Unlike a 'hard' system that emphasizes techniques, a 'soft' system involves people (Blockley, Godfrey 2000). It explores interpersonal and inter-organizational relationships (Pryke, Smyth 2006). A key focus of using this approach is to replace adversarial or confrontational relationships with cooperative or collaborative relationships (Gil 2009; Meng et al. 2011). The relationship approach does not mean an exclusion of contracts. Instead, it views contracts as relationships rather than as discrete transactions (Chan et al. 2009). Effective relationship management makes it possible to create a good and harmonious working environment. Another reason for the increasing attention to working relationship is that it can provide flexible, farsighted and proactive management to address complex and dynamic processes (Turner 2004; Rahman, Kumaraswamy 2004).

Trust can be considered as a quality of interpersonal and inter-organizational relationships (Lau, Rowlinson 2009).

Corresponding author: Xianhai Meng

E-mail:x.meng@qub.ac.uk 
It was classified by Sako (1992) into contractual trust, competence trust and goodwill trust, which describe trust at three different levels. Over the years, this classification has been followed by a large number of researchers, such as Burchell and Wilkinson (1997) in general and Cheung et al. (2003) in construction. According to Sako (1992), contractual trust is characterized by each party upholding an ethical standard of keeping promise and adhering to the written or verbal agreements; competence trust is characterized by each party's ability to carry out the tasks and perform the roles competently; and goodwill trust is characterized by each party's willingness to do more than what is formally promised and an absence of opportunistic behavior. Obviously, keeping promise and having ability generate contractual trust and competence trust, respectively. On the other hand, the willingness to proceed beyond explicit commitments engenders goodwill trust (Sako, Helper 1998).

Subsequent to Sako (1992), some other researchers viewed trust from a confidence perspective. For example, Sabel (1993) defined trust as the mutual confidence that no party to an exchange will exploit another's vulnerability. Similarly, Das and Teng (1998) believed that trust is a source of confidence because one party has a positive attitude towards another's behavior. Although different authors may use different terms when describing trust, the expectation of keeping promise, belief in ability, hope for goodwill and confidence in behavior are generally recognized as the main attributes of trust, among which the former three are enablers, whereas the latest one is a result. In a trust relationship, the trustor is a person or an organization that trusts another, whereas the trustee is a person or an organization that is trusted (Smyth et al. 2010). If Sako's trust classification and the so-called 'confidence' theory are combined, it is obvious that the trustor will be confident of the trustee if the trustee keeps promise, has ability and holds goodwill.

There have been increasing research efforts to suggest that trust is crucial to the effectiveness of relationship management (Wong et al. 2000). A consensus is that cooperation or collaboration is about the management of a relationship that must be trust-based (Cheung et al. 2003; Bemelmans et al. 2012). Trust has important implications for both clients and other project participants, such as main contractors and subcontractors (Khalfan et al. 2007). It acts as an emotional bond that ties the parties together (Pinto et al. 2009; Girmscheid, Brockmann 2010). Mutual trust is particularly important when a project is full of risk/uncertainty and a relationship is characterized by vulnerability (Huemer 2004). It helps to reinforce expectation, belief, hope and confidence and to overcome risk/uncertainty (Wong et al. 2008). On the other hand, relationship dysfunction often arises from mistrust (Lewicki et al. 1998). Suspicion is a source of conflict and confrontation (Zaghloul, Hartman 2003).

Trust is not isolated. Instead, it interacts with other relationship indicators. This has been discussed by a certain amount of existing literature. For example,
$\mathrm{Ng}$ et al. (2002) pointed out that mutual trust is a key to good communication. Trust opens the lines of communication (Wong et al. 2000), whereas the absence of trust forms a barrier to effective communication (McDermott et al. 2004). Although a great deal of research attention has been placed to analyze the interaction between trust and other relationship indicators, few empirical studies have been conducted to examine the significance of the association between trust and each relationship indicator. As a result, there is no statistical evidence for the significant contribution of trust to relationship development. At the same time, there is no clear understanding of the relative importance of trust to different relationship indicators. Therefore, nobody knows whether trust has equal or unequal contribution to each relationship indicator. This is the first gap in knowledge, which tends to affect the success of relationship management during the project.

On the other hand, trust is believed to have a potential influence on the successful completion of a construction project (Munns 1995). For this reason, the Contracting Task Force of the Construction Industry Institute (CII) carried out a research project on the cost-trust relationship in the United States construction industry, based on which project cost is suggested to be significantly correlated with trust (CII 1994). From another point of view, Zaghloul and Hartman (2003) identified that mistrust is a driver to increase the total cost of a project. However, there is a lack of empirical studies to date on the link between trust and other performance indicators, such as time and quality. As a result, it is not possible to evaluate the impact of trust on project performance in a systematic way. In addition, whether trust has equal or unequal effect on time, cost and quality performance is not known. This becomes another gap in knowledge, which tends to affect the successful delivery of a project.

An empirical investigation, including a questionnaire survey and a series of expert interviews, is made in the UK construction industry to bridge the knowledge gaps mentioned above. This study focuses on interorganizational trust. It attempts to identify the contribution of trust to relationship development and to analyze the influence of trust on performance improvement. It helps to answer the research questions concerning: (1) whether trust has a significant contribution to relationship development; (2) what relationship indicators are more likely to be affected by trust; (3) whether trust has a major influence on performance improvement; (4) what performance indicators are more likely to be affected by trust; (5) whether the increase of trust is significantly associated with the reduction in monitoring and control; and (6) how trust interacts with working relationship and project performance. The findings of this study provide strong evidence that fostering trust contributes to cooperation or collaboration, which in turn ensures project success. Based on the findings in this study, construction practitioners and organizations can obtain a thorough understanding of the role of trust in achieving best practice. 


\section{Relationship and performance indicators}

Trust builds a platform for project parties to cooperate or collaborate with each other, whose relationship is described by a list of key factors. According to Bennett and Jayes (1995), the three key features of a partnering relationship are mutual objectives, problem solving and continuous improvement. Rahman and Kumaraswamy (2004) revealed that the fundamental element of collaborative working is mutual benefits and risk sharing. Chan et al. (2004) believed that communication for conflict resolution, willingness to share resources, clear definitions of responsibilities, commitment to win-win, and partnering processes are the underlying factors for cooperation or collaboration. Although different authors may use different terms for a relationship indicator, they are synonymous. For example, both mutual benefits and win-win have the same meaning - benefit sharing. The common factors identified by these authors and other construction researchers, such as Crane et al. (1999), Walker et al. (2002) and Radziszewska-Zielina (2010), include definition of roles and responsibilities, mutual objectives, joint working, open communication, cost data transparency, problem solving, continuous improvement, and benefit/ risk sharing. The key factors commonly identified are used as key relationship indicators in this study.

Completion on time, on budget and with the specified quality is widely recognized as the three major objectives of a project (Chan, A. P. C., Chan, A. P. L. 2004). Since construction projects are becoming larger and more complex, it is not easy to achieve these major objectives (Harris et al. 2006). Many construction projects, especially the projects that adopt traditional practices, suffer from time delays, cost overruns and quality defects (Sun, Meng 2009). Therefore, there is a need to improve project performance more effectively. Time, cost and quality are generally regarded as 'hard' performance measures (Crawford, Pollack 2004). In addition to 'hard' measures, some existing studies have paid attention to 'soft' measures for project performance. For example, Belout and Gauvreau (2004) identified communication as a success factor, and Radujković et al. (2010) considered cooperation as a key indicator. Actually, these key factors have been fully or partly reflected by the relationship indictors mentioned above. For this reason, this study adopts time, cost and quality as key performance indicators.

\section{Research methods}

This study adopts a combination of quantitative and qualitative methodologies. It starts with a comprehensive review of relevant literature. The literature review helps to identify the main attributes of trust, key indicators of relationship and key indicators of performance. It also helps to analyze the strengths and weaknesses of existing studies on trust and to identify a need for this empirical investigation. Following the literature review, a question- naire survey is conducted in the UK construction industry because it is an easy way of gathering information from many people (Gillham 2000). This is a project-specific investigation, which means that each questionnaire response represents a completed project. As a result of the questionnaire survey, 101 responses are collected from industrial practitioners like project managers, procurement managers, contract managers and performance managers who have adequate experience in managing construction projects. The respondents are involved in various construction organizations, such as project clients, main contractors, management consultancies and subcontractors. The questionnaire consists of four sections - respondent information, trust and control, working relationship, and project performance, to fit for the research purpose.

The first section of the questionnaire is used to collect the information about a respondent's role and organization. In the second section, two questions are asked to rate a respondent's perception of trust and the reduction in monitoring and control according to a fourpoint Likert scale ranging from Strongly Disagree $(=1)$ to Strongly Agree $(=4)$. As a result, trust is measured across the spectrum from the very negative end to the very positive end. Similarly, a respondent's perception of eight relationship indicators is rated in the third section in terms of a four-point Likert scale. The fourth section is related to project performance. Time certainty refers to whether or not a project is completed on time: 1 for on time completion and 2 for time delay. The two options for cost certainty are: 1 for on budget completion and 2 for cost overrun. Quality performance considers the condition of the completed project with respect to quality defects by using a five-point Likert scale $(1=$ Defect free; 2 = Some defects without significant impact on the client; 3 = Some defects with some impact on the client; $4=$ Major defects with major impact on the client; and $5=$ Totally defective).

The answers to the questions in the second, third and fourth sections measure trust, relationship and performance in each surveyed project, which will be used to analyze the impact of trust on working relationship and project performance later in this paper. On the whole, the questionnaire survey serves as the main instrument of empirical data collection. In addition to the questionnaire survey, over ten industrial experts are further interviewed to get a deeper insight into the role of trust. An interview takes full advantage of the direct interaction between people (Robson 2002). In this study, expert interviews help to analyze whether it is possible to break down a project management system into input, process and output. They also help to identify whether trust is an input or an output of the project management system. As a result, interviewing industrial experts becomes an important complementary method in this research and contributes to the establishment of a model that links trust with relationship and performance. 


\section{Analysis of questionnaire responses}

Based on the 101 questionnaire responses, the quantitative date are analyzed statistically in this section, focusing on the contribution of trust to relationship development, the influence of trust on performance improvement, and the association between the increase of trust and the reduction in monitoring and control.

\subsection{Contribution of trust to relationship development}

Since both trust and eight relationship indicators are ordinal variables, a Gamma test is used to examine the association between trust and each relationship indicator. The test results are presented in Table 1. The significance level represented by $p$-value refers to the level of an association between two variables: (1) if $p$-value is less than or equal to 0.001 , there is an extremely significant association between two variables; (2) if $p$-value is greater than 0.001 but less than or equal to 0.01 , the association is suggested to be highly significant; (3) if p-value is greater than 0.01 but less than or equal to 0.05 , two variables are identified as significantly associated; (4) if $p$-value is greater than 0.05 but less than or equal to 0.1 , the association is often considered as marginally significant; and (5) if p-value is greater than 0.1 , no significant association is found between two variables. Generally, the smaller the significance level is, the closer the association between two variables has.

As shown in Table 1, an important finding is that almost all key relationship indicators are either extremely significantly or highly significantly or significantly associated with trust, and meanwhile there is no insignificant association between trust and any relationship indicator. The finding provides quantitative evidence for the significant contribution of trust to the development of cooperative or collaborative relationships. By comparison, mutual objectives, joint working, definition of roles and responsibilities, and problem solving are most likely to be affected by trust because they all have extremely significant associations with trust. For example, the agreement and achievement of mutual objectives extremely significantly depends on whether there is enough trust between the parties in a project. The same applies to joint working, clear definition of roles and responsibilities, and effective problem solving. A ranking is provided in Table 1 for eight relationship indicators in terms of their associations with trust.

Some relationship indicators have closer associations with trust than others. If a comparison is made between open communication and cost data transparency, for example, it is easy to find that open communication is highly significantly associated with trust at the 0.002 level, whereas cost data transparency is only significantly associated with trust at the 0.050 level. This indicates that, although trust at a certain level facilitates the open exchange of ideas and information, whether important cost data can be shared or not is still a question. Compared to open communication, cost data transparency can only be achieved when there is a higher level of trust. Another finding is the marginally significant association between trust and benefit/risk sharing at the 0.062 level. The finding seems to contradict with the statement in previous studies, such as Li et al. (2000), which emphasized the importance of trust to benefit and risk sharing. As a matter of fact, it reveals that, compared to other relationship indicators, benefit and risk sharing are least likely to be affected by trust in practice. Even if there is a high degree of trust, it does not necessarily means that major benefits and risks can be easily shared between the parties. To some extent, the findings about cost data transparency and benefit/risk sharing reflect the fact that a lack of shared culture still dominates the construction industry.

\subsection{Influence of trust on performance improvement}

Table 2 presents the influence of trust on project performance. For each questionnaire response, Strongly Disagree with trust means high mistrust, and Disagree with trust means low mistrust. On the other hand, Agree and Strongly Agree with trust describe low trust and high trust, respectively. As a result, trust is rated at four different levels from the very negative to the very positive. Since there are no responses to totally defective, the responses to some defects with some impact and major defects with major impact can be merged into defective projects, and meanwhile the responses to defect free and some defects without significant impact can be merged into non-defective projects. Based on the mergence, quality certainty is defined. This new variable consists of two options: one is a non-defective project and the other is

Table 1. Association between trust and key relationship indicators

\begin{tabular}{|c|c|c|c|c|c|}
\hline & Relationship indictor & $\gamma$-value & p-value & Ranking & Significance \\
\hline \multirow{9}{*}{ Trust } & Mutual objectives & 0.879 & 0.000 & 1 & \multirow{4}{*}{ Extremely significant } \\
\hline & Joint working & 0.696 & 0.000 & 2 & \\
\hline & Definition of roles and responsibilities & 0.646 & 0.000 & 3 & \\
\hline & Problem solving & 0.544 & 0.001 & 4 & \\
\hline & Open communication & 0.501 & 0.002 & 5 & \multirow{2}{*}{ Highly significant } \\
\hline & Continuous improvement & 0.470 & 0.009 & 6 & \\
\hline & Cost data transparency & 0.277 & 0.050 & 7 & Significant \\
\hline & Benefit/risk sharing & 0.263 & 0.062 & 8 & Marginally significant \\
\hline & - & - & - & - & Not significant \\
\hline
\end{tabular}


Table 2. Relationship between trust and key performance indictors

\begin{tabular}{lcccc}
\hline Performance indicator & $\begin{array}{c}\text { High } \\
\text { mistrust } \\
\mathrm{n}=2\end{array}$ & $\begin{array}{c}\text { Low } \\
\text { mistrust } \\
\mathrm{n}=22\end{array}$ & $\begin{array}{c}\text { Low trust } \\
\mathrm{n}=62\end{array}$ & $\begin{array}{c}\text { High trust } \\
\mathrm{n}=15\end{array}$ \\
\hline Percentage of delayed projects & $50.0 \%$ & $40.9 \%$ & $34.4 \%$ & $33.3 \%$ \\
\hline Percentage of overspent projects & $100.0 \%$ & $22.7 \%$ & $26.7 \%$ & $13.3 \%$ \\
\hline Percentage of defective projects & $100.0 \%$ & $31.8 \%$ & $13.4 \%$ & $6.7 \%$ \\
\hline
\end{tabular}

a defective project. Similar to time and cost certainties mentioned above, quality performance is also measured in terms of its certainty.

As shown in Table 2, the percentages of delayed, overspent and defective projects are generally ranked in descending order from high mistrust to high trust. Obviously, the lower the percentage of these projects is, the smaller the likelihood of poor performance has. For this reason, the ranking in descending order demonstrates that poor performance is gradually reduced following the step-wise development of mutual trust. Inconsistent to the general trend, an abnormality is that $26.7 \%$ of the projects with low trust suffer from cost overruns, which is greater than $22.7 \%$, the percentage of overspent projects with low mistrust. The finding reveals that cost performance at a low level of trust may not necessarily be better than that at a low level of mistrust. The phenomenon can be explained by the emphasis on monitoring and control over project cost when mistrust exists between the parties. For cost performance, monitoring and control does not always imply coercion. Instead, it may help, to a certain extent, to achieve the cost objective. By comparison, only a high level of trust will definitely result in better cost performance because the percentage of overspent projects with high trust is $13.3 \%$.

Since time, cost and quality certainties are all nominal variables, a Chi-square test is further used to examine whether there are significant associations between trust and time, cost and quality certainty. As a result, an insignificant association is found between trust and time certainty ( $p$-value $=0.916)$. On the other hand, trust is marginally significantly associated with cost certainty $(p$-value $=0.066)$, and there is a highly significant association between trust and quality certainty ( $p$-value $=$ 0.003 ). In this research, trust proves to have a marginally significant effect on the reduction in cost overruns and a highly significant effect on the reduction in quality defects, but its effect on the avoidance of time delays is not significant. In terms of cost performance, the finding in this study is similar to the cost-trust relationship derived from the CII's Task Force in 1994. Unlike the significant correlation between trust and project cost reported by CII (1994), only a marginally significant association is found in this study between trust and cost certainty. By comparison, quality certainty is most likely to be affected by trust, whereas time certainty is least likely to be affected by trust. For this reason, construction practitioners and organizations should pay attention to trust when address- ing quality and cost problems. On the other hand, building and developing trust to improve time performance should have a low priority.

\subsection{Inverse association between trust and monitoring and control}

In addition to relationship and performance, another key issue in relation to trust is monitoring and control. This is because the primary value of trust is the reduction in monitoring and control that is required to manage less trusted partners (Swan et al. 2005). When it is possible to fully trust a partner, there is no need to monitor and control his behavior (Das, Teng 1998). Monitoring and control comes into play only when adequate trust is not present (Costa et al. 2001). However, whether there is a significant association between trust and the reduction in monitoring and control needs to be justified. For this reason, Gamma is used again to test the association between the two ordinal variables. The test result shows that the reduction in monitoring and control is significantly associated with the increase of trust at the 0.041 level. The finding reinforces previous studies, such as Swan et al. (2005), by providing quantitative evidence. It reveals the inverse association between trust and monitoring and control, namely monitoring and control are reduced when trust is increased.

\section{Model development}

Based on the literature review and the analysis of questionnaire responses, a model is developed to distinguish trust-based relationship management from the traditional mechanism that is based on contract and relies on monitoring and control (Fig. 1). Another purpose of the model development is to establish a link between trust, working relationship and project performance. In addition to the literature review and the questionnaire survey, expert interviews in this study contribute to the development of the model.

\subsection{Analysis of interview results}

The interviewees in this study reveal that there has been an increasing shift in management focus from contractbased monitoring and control to trust-based relationship management. The shift in management focus does not imply the ignorance of project management techniques. Instead, more attention is paid to the importance of trust and relationship to project success. The finding is a con- 


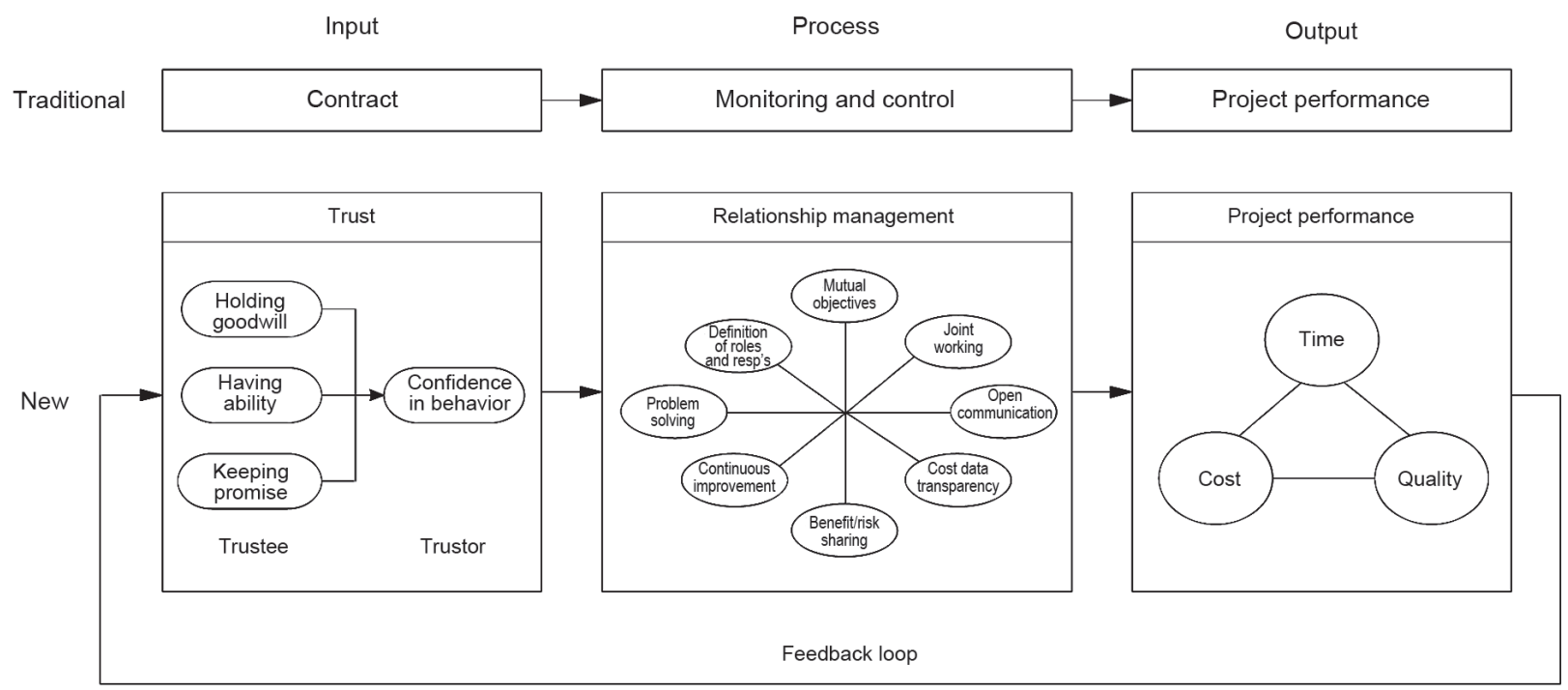

Fig. 1. Trust-based management versus monitoring and control-focused management

tribution of expert interviews. According to Franceschini et al. (2007), a management system can be broken down into input, process and output. The interviewees in this study confirm that a project management system is also characterized by the breakdown into input, process and output. In a traditional system, contract is an input and monitoring and control represent project management processes. When a trust-based relationship approach is adopted, trust should be an input and working relationship becomes a key focus of project management processes. This is another contribution of expert interviews. For both the traditional mechanism and the new approach, project performance in terms of time, cost and quality is always considered as an output of the project management system.

Trust has been viewed by most existing studies as an input of relationship management. For example, Cheung et al. (2011) identified trust as the key driver in facilitating cooperation and collaboration between the parties. Some other authors, however, have recognized trust as an output of relationship management. For example, Davis and Love (2011) believed that mutual trust is encouraged through relationship development. As a result, whether trust should be an input or an output becomes ambiguous. According to the interviewees in this study, trust is both an input and an output. "A certain degree of trust is needed in order to establish a collaborative relationship, but trust then develops as a result of the collaborative working." The identification of the dual role of trust may be the most important contribution of expert interviews, based on which a feedback loop is added in the model. The feedback loop links the current project with the next project, which makes it possible for project participants to enhance mutual trust in a continuous manner and sustain a long-term relationship.

\subsection{Model descriptions and implications}

There are two ways of working in construction practice. Contractual arrangements provide a basis for the traditional way of working so that they are regarded as the input of the project management system. During a project, monitoring and control are a central theme and one party treats another like an adversary. As the output of the project management system, performance in terms of time, cost and quality depends on the effectiveness of monitoring and control. Although traditional practitioners try to achieve project success through strict monitoring and control, little or no attention to working relationship undermines their value. Heavy reliance on monitoring and control also results from mistrust and suspicion. Without mutual trust, the parties in a project pull in opposite directions and compete with each other. The lack of a good and harmonious working environment causes various performance problems and makes it difficult to ensure project success.

A project can be done differently. Unlike traditional practices, the new working approach is built on mutual trust and dependent on cooperative or collaborative relationships. As the main attributes of trust, promise keeping, having ability and holding goodwill characterize the trustee. As a result of the trustee's good characters, the trustor has confidence in the trustee's behavior. Trust saves the costs of monitoring and control. Rooted in trust, the parties in a project work together as partners. Relationship management for cooperation or collaboration becomes the primary focus of project management, which is represented by the key relationship indicators in eight dimensions. Trust plays a pivotal role in relationship management during a project. It enables project participants to make mutual efforts and concentrate on the overall success of a project. The creation of a good and harmonious working environment leads to the significant 
improvement of project performance in terms of time, cost and quality.

The input-process-output model developed in this study clarifies what are required for a project, what need to be addressed during a project, and what will be achieved from a project. It provides a useful tool to look at project management in different ways and with different focuses. Construction practitioners and organizations may benefit from this model in the following areas:

- Being aware of the difference between trust-based relationship management and monitoring and control-focused process management;

- Realizing the importance of trust to the development of relationship management and the improvement of project performance; and

- Identifying the three major ways of fostering trust: fulfilling commitments, performing competently, and offering goodwill.

\section{Further discussion}

As discussed above, monitoring and control can be reduced when mutual trust is increased. For this reason, it is possible to consider pure reliance on trust and pure reliance on monitoring and control as the two extremes of a management spectrum. The importance of trust to relationship development and performance improvement is highlighted in this research. However, it does not necessarily means that trust is a panacea and can replace everything. It is a misunderstanding that pure reliance on trust is encouraged in this research. The analysis of questionnaire responses shows that cost performance at a low level of trust is not as good as that at a low level of mistrust because the latter has stronger monitoring and control. On the other hand, the analysis of interview results shows that the shift in management focus from monitoring and control to trust and relationship is not to ignore project management techniques. In reality, monitoring and control are still needed more or less even if a trust relationship is established between project parties, especially when the degree of trust is not high. It is important to realize that infusing some 'soft' elements into the 'hard' management system so that projects can be managed and completed more effectively and efficiently is the primary reason for highlighting the importance of trust and shifting the focus of project management.

In this research, expert interviews contribute to the identification of the role of trust. In addition to the role of trust, in-depth interviews provide further information about how to develop and maintain trust. According to the interviewees, it is not appropriate to expect to build trust at one go. Instead, project participants have to consider this key issue from a long-term perspective. Some examples given by the interviewees illustrate that trust is developed step by step during a project or through a number of projects. In addition to each party fulfilling commitments, performing competently and offering goodwill, an interesting finding during the interviews is that good personal relationship between the top management of construction organizations is often an initiator of inter-organizational trust. On the other hand, a consensus of the interviewees is that trust is hard to build, but easy to break. For this reason, project participants must make enough efforts to maintain trust once it is established between them. Otherwise, they have to make much more efforts to rebuild trust if it is broken. In this sense, maintaining trust is as important as building trust or may be even more important than building trust.

\section{Conclusions}

There are two reasons for adopting the new paradigm that is based on trust: one is the development of relationship management, and the other is the improvement of project performance. First of all, trust plays an important role in developing cooperative or collaborative relationships. Therefore, trust can be described as the glue that binds the partners together and as the lubricant that makes relationship management smooth. Working relationship has a multi-dimensional structure that is portrayed by a list of key relationship indicators. It is evident that the contribution of trust to relationship development is not balanced. This means that trust has more importance to some relationship indicators than to others. The finding helps construction practitioners and organizations to identify what relationship indicators are more likely to be affected by trust, based on which they can take appropriate actions to facilitate cooperation and collaboration more effectively by fostering trust.

Trust also has a major influence on performance improvement. Generally, project performance is improved step by step following the enhancement of mutual trust. This is because trust contributes to the development of cooperative or collaborative relationships, which in turn promotes the improvement of project performance. As a result, a link is established between trust, relationship management and project performance, in which trust is the fundamental. Similar to relationship development, trust has an unbalanced influence on project performance in terms of time, cost and quality. The unequal contribution of trust to relationship development and performance improvement enables construction practitioners and organizations to better understand the interaction between trust and other key factors in the project environment. In addition to the role of trust, construction practitioners and organizations have to recognize the way and the challenge of developing and maintaining trust. Only if they have a thorough understanding of trust, is it possible for them to drive trust to strive for project success.

\section{References}

Al-Jibouri, S. H. 2003. Monitoring systems and their effectiveness for project cost control in construction, International Journal of Project Management 21(2): 145-154. http://dx.doi.org/10.1016/S0263-7863(02)00010-8 
Badenfelt, U. 2011. Fixing the contract after the contract is fixed: a study of incomplete contracts in IT and construction projects, International Journal of Project Management 29(5): 568-576.

http://dx.doi.org/10.1016/j.ijproman.2010.04.003

Belout, A.; Gauvreau, C. 2004. Factors influencing project success: the impact of human resource management, International Journal of Project Management 22(1): 1-11. http://dx.doi.org/10.1016/S0263-7863(03)00003-6

Bemelmans, J.; Voordijk, H.; Vos, B.; Buter, J. 2012. Assessing buyer-supplier relationship management: multiple case-study in the Dutch construction industry, Journal of Construction Engineering and Management 138(1): $163-176$.

http://dx.doi.org/10.1061/(ASCE)CO.1943-7862.0000418

Bennett, J.; Jayes, S. 1995. Trusting the team: the best practice guide to partnering in construction. Reading: Reading Construction Forum. 82 p.

Blockley, D.; Godfrey, P. 2000. Doing it differently: systems for rethinking construction. London: Thomas Telford. 320 p. http://dx.doi.org/10.1680/didsfrc. 27480

Burchell, B.; Wilkinson, F. 1997. Trust, business relationships and the contractual environment, Cambridge Journal of Economics 21(2): 217-237. http://dx.doi.org/10.1093/oxfordjournals.cje.a013667

Chan, A. P. C.; Chan, D. W. M.; Chiang, Y. H.; Tang, B. S.; Chan, E. H. W.; Ho, K. S. K. 2004. Exploring critical success factors for partnering in construction projects, Journal of Construction Engineering and Management 130(2): 188-198. http://dx.doi.org/10.1061/(ASCE)07339364(2004)130:2(188)

Chan, A. P. C.; Chan, A. P. L. 2004. Key performance indicators for measuring construction success, Benchmarking: An International Journal 11(2): 203-221. http://dx.doi.org/10.1108/14635770410532624

Chan, A. P. C.; Chan, D. W. M.; Yeung, J. F. 2009. Relational contracting for construction excellence: principles, practices and case studies. Oxon: Spon. 338 p.

Cheung, S. O.; Ng, T. S. T.; Wong, S.; Suen, H. C. H. 2003. Behavioral aspect in construction partnering, International Journal of Project Management 21(5): 333-343. http://dx.doi.org/10.1016/S0263-7863(02)00052-2

Cheung, S. O.; Wong, W. K.; Yiu, T. W.; Pang H. Y. 2011. Developing a trust inventory for construction contracting, International Journal of Project Management 29(2): 184196. http://dx.doi.org/10.1016/j.ijproman.2010.02.007

Construction Industry Institute (CII). 1994. The cost-trust relationship in the construction industry. SD-100, Austin: CII. 207 p.

Costa, A. C.; Roe, R. A.; Taillieu, T. 2001. Trust with teams: the relation with performance effectiveness, European Journal of Work and Organizational Psychology 10(3): 225-244. http://dx.doi.org/10.1080/13594320143000654

Crane, T. G.; Felder, J. P.; Thompson, P. J.; Thompson, M. G.; Sanders, S. R. 1999. Partnering measures, Journal of Management in Engineering 15(2): 37-42. http://dx.doi.org/10.1061/(ASCE)0742-597X(1999)15:2(37)

Crawford, L.; Pollack, J. 2004. Hard and soft projects: a framework for analysis, International Journal of Project Management 22(8): 645-653.

http://dx.doi.org/10.1016/j.ijproman.2004.04.004

Das, T. K.; Teng, B. S. 1998. Between trust and control: developing confidence in partner cooperation in alliances, Academy of Management Review 23(3): 491-512. http://dx.doi.org/10.2307/259291

Davis, P.; Love, P. 2011. Alliance contracting: adding value through relationship development, Engineering, Construction and Architectural Management 18(5): 444-461. http://dx.doi.org/10.1108/09699981111165167
Franceschini, F.; Galetto, M.; Maisano, D. 2007. Management by measurement: designing key indicators and performance measurement systems. Berlin: Springer. 242 p.

Gil, N. 2009. Developing cooperative project client-supplier relationships: how much to expect from relational contracts?, California Management Review 51(2): 144-169. http://dx.doi.org/10.2307/41166484

Gillham, B. 2000. Developing a questionnaire. London: Continuum. 93 p.

Girmscheid, G.; Brockmann, C. 2010. Inter- and intraorganizational trust in international construction joint ventures, Journal of Construction Engineering and Management 136(3): 353-360.

http://dx.doi.org/10.1061/(ASCE)CO.1943-7862.0000142

Harris, F.; McCaffer, R.; Edum-Fotwe, F. 2006. Modern construction management. $6^{\text {th }}$ ed. Oxford: Blackwell. $680 \mathrm{p}$.

Huemer, L. 2004. Activating trust: the redefinition of roles and relationships in an international construction project, International Marketing Review 21(2): 187-201. http://dx.doi.org/10.1108/02651330410531394

Khalfan, M. M. A.; McDermott, P.; Swan, W. 2007. Building trust in construction projects, Supply Chain Management: An International Journal 12(6): 385-391. http://dx.doi.org/10.1108/13598540710826308

Lann, A.; Noorderhaven, N.; Voordijk, H.; Dewulf, G. 2011. Building trust in construction partnering projects: an exploratory case-study, Journal of Purchasing and Supply Management 17(2): 98-108.

http://dx.doi.org/10.1016/j.pursup.2010.11.001

Lau, E.; Rowlinson, S. 2009. Interpersonal trust and inter-firm trust in construction projects, Construction Management and Economics 27(6): 539-554. http://dx.doi.org/10.1080/01446190903003886

Lewicki, R. J.; McAllistair, D. J.; Bies, R. J. 1998. Trust and distrust: new relationships and realities, Academy of Management Review 23(3): 438-458. http://dx.doi.org/10.2307/259288

Li, H.; Cheng, E. W. L.; Love, P. E. D. 2000. Partnering research in construction, Engineering, Construction and Architectural Management 7(1): 76-92. http://dx.doi.org/10.1108/eb021134

McDermott, P.; Khalfan, M. M. A.; Swan, W. 2004. An exploration of the relationship between trust and collaborative working in the construction sector, Construction Information Quarterly 6(4): 140-146.

Meng, X.; Sun, M.; Jones, M. 2011. Maturity model for supply chain relationships in construction, Journal of Management in Engineering 27(2): 97-105. http://dx.doi.org/10.1061/(ASCE)ME.1943-5479.0000035

Munns, A. K. 1995. Potential influence of trust on the successful completion of a project, International Journal of Project Management 13(1): 19-24. http://dx.doi.org/10.1016/0263-7863(95)95699-E

Ng, S. T.; Rose, T. M.; Mak, M.; Chen, S. E. 2002. Problematic issues associated with project partnering: the contractor perspective, International Journal of Project Management 20(6): 437-449. http://dx.doi.org/10.1016/S0263-7863(01)00025-4

Pinto, J. K.; Slevin, D. P.; English, B. 2009. Trust in projects: an empirical assessment of owner/contractor relationships, International Journal of Project Management 27(6): 638648. http://dx.doi.org/10.1016/j.ijproman.2008.09.010

Pryke, S.; Smyth, H. 2006. The management of complex projects: a relationship approach. Oxford: Blackwell. 328 p.

Radujković, M.; Vukomanović, M.; Dunović, I. B. 2010. Application of key performance indicators in South-Eastern European countries, Journal of Civil Engineering and Management 16(4): 521-530.

http://dx.doi.org/10.3846/jcem.2010.58 
Radziszewska-Zielina, E. 2010. Methods for selecting the best partner construction enterprise in terms of partnering relations, Journal of Civil Engineering and Management 16(4): 510-520. http://dx.doi.org/10.3846/jcem.2010.57

Rahman, M. M.; Kumaraswamy, M. M. 2004. Contracting relationships trends and transactions, Journal of Management in Engineering 20(4): 147-161. http://dx.doi.org/10.1061/ (ASCE)0742-597X(2004)20:4(147)

Robson, C. 2002. Real world research. $2^{\text {nd }}$ ed. Oxford: Blackwell. 599 p.

Sabel, C. F. 1993. Studied trust: building new forms of cooperation in a volatile economy, Human Relations 46(9): 11331170. http://dx.doi.org/10.1177/001872679304600907

Sako, M. 1992. Prices, quality and trust: inter-firm relations in Britain and Japan. Cambridge: Cambridge University Press. 270 p. http://dx.doi.org/10.1017/CBO9780511520723

Sako, M.; Helper, S. 1998. Determinants of trust in supplier relations: evidence from the automotive industry in Japan and the United States, Journal of Economic Behavior and Organization 34(3): 387-417.

http://dx.doi.org/10.1016/S0167-2681(97)00082-6

Smyth, H.; Fitch, T. 2009. Application of relationship marketing and management: a large contractor case study, Construction Management and Economics 27(4): 399-410. http://dx.doi.org/10.1080/01446190902777365

Smyth, H.; Gustafsson, M.; Ganskau, E. 2010. The value of trust in project business, International Journal of Project Management 28(2): 117-129.

http://dx.doi.org/10.1016/j.ijproman.2009.11.007

Sun, M.; Meng, X. 2009. Taxonomy for change causes and effects in construction projects, International Journal of Project Management 27(6): 560-572. http://dx.doi.org/10.1016/j.ijproman.2008.10.005
Swan, W.; McDermott, P.; Khalfan, M. M. A.; Cooper, R.; Rees, C.; Wood, G. 2005. The development of trust inventory, Journal of Construction Procurement 11(1): $40-54$.

Turner, R. 2004. Farsighted project contract management: incomplete in its entirety, Construction Management and Economics 22(1): 75-83. http://dx.doi.org/10.1080/0144619042000186077

Walker, A. 2007. Project management in construction. Oxford: Blackwell. 328 p.

Walker, D. H. T.; Hampson, K.; Peters, R. 2002. Project alliancing vs project partnering: a case study of Australian National Museum Project, Supply Chain Management: An International Journal 7(2): 83-91. http://dx.doi.org/10.1108/13598540210425830

Wong, E. S.; Then, D.; Skitmore, M. 2000. Antecedents of trust in intra-organizational relationships within three Singapore public sector construction project management agencies, Construction Management and Economics 18(7): 797-806. http://dx.doi.org/10.1080/014461900433087

Wong, W. K.; Cheung, S. O.; Yiu, T. W.; Pang, H. Y. 2008. A framework for trust in construction contracting, International Journal of Project Management 26(8): 821-829. http://dx.doi.org/10.1016/j.ijproman.2007.11.004

Zaghloul, R.; Hartman, F. 2003. Construction contracts: the cost of mistrust, International Journal of Project Management 21(6): 419-424. http://dx.doi.org/10.1016/S0263-7863(02)00082-0

Xianhai MENG. He is currently a Lecturer in Construction and Project Management at Queen's University Belfast, UK. Previously, he was an Associate Professor at Tsinghua University, Beijing, China. His research interests include project management, supply chain management, performance measurement and improvement, procurement and contract strategies, construction economics and finance, and public private partnerships. 